\title{
INFLUENCE OF SOIL MOISTURE CONTENT ON SOIL SOLARIZATION EFFICIENCY
}

\author{
M. M. IBRAHIM*
}

\begin{abstract}
$\underline{\text { ABSTRACT }}$
The experiments of this study were carried out to investigate how soil temperature is influenced by different soil moisture content regimes during soil solarization. The ten plots were brought to five volumetric moisture regimes $\left(\boldsymbol{M}_{1}-M_{5}\right)$. The moistened soils were mulched with 100 um-thick black and transparent polyethylene covers. Maximum and minimum soil temperatures for depths of 10, 20 and $30 \mathrm{~cm}$ were recorded from 1 June to 30 July, 2010 at Faculty of Agriculture, Omar Al-Mukhtar University, El-Beida, Libya.

For black and transparent covers, the results showed that the maximum soil temperatures decreased with increasing soil moisture content. Moreover, soil solarization efficiency decreased with increasing moisture content. The higher temperatures under the $\boldsymbol{M}_{\mathbf{4}}\left(0.39\right.$ and $0.37 \mathrm{~m}^{3} / \mathrm{m}^{3}$ at start solarization) irrigation regime resulted in faster eradication of the pathogenic fungus.
\end{abstract}

Keywords: Solar heating; Solarization; Mulching; Polyethylene.

\section{INTRODUCTION}

$\mathrm{S}$ ustainable agricultural system is to economize on inputs into crop production. One way that this objective can be achieved is through integrated management of plant diseases rather than sole reliance on fungicides.

Though soil-borne pests can be controlled in fruit trees by pre-planting application of pesticides, including the fumigants methyl bromide, chloropicrin and metam sodium (Katan, 1984), the use of these chemicals is often undesirable owing to their toxicity to animals and human beings, their residual toxicity in plants and soils, their complexity, and the high cost of treatment.

\footnotetext{
*Assist. Prof., Ag. Eng. Dept., Fac. of Agric., Cairo Univ.
} 
Furthermore, restrictions on the use of soil-applied pesticides appear to be eminent as future environmental legislation is being implemented. To overcome this problem and remove soilborne pests, solarization is considered the best technique (Di Primo et al., 2003).

Soil solarization is a process in which soil temperature is increased by using solar radiation as an energy source. It was initially intended as a method for controlling soil pathogens (Katan et al., 1976)

Solarization is known as a method of heating the soil by using polyethylene sheets as mulching over moistened soil, to retain radiation from the sun during the hot season (Katan et al., 1976; Horowitz et al., 1983). Much has been written about the soil solarization, which is used successfully to control soil-borne pathogens and weeds (Al-Kayssi and Al-Karaghouli, 1991). In all the previous work, only polyethylene sheets were concerned as a mulching material. Polyethylene sheet covering irrigated soil transmits less solar global radiation. Because polyethylene sheets are hydrophobic, water condenses on them in very small droplets, thus increasing reflectance (Avissar et al., 1986). On the other hand, an additional reduction in net radiative flux under polyethylene mulch is due to its relatively higher transmittance to infrared radiation (Avissar et al., 1986).

Solarization is practiced in regions of intense sunlight, such as the tropics or arid regions that have little cloud cover. Moistened seedbeds are covered with clear polyethylene mulch and remain covered for an extended period of time. During the solarization period, $85-95 \%$ of radiation from sunlight penetrates the clear mulch and heats the soil (Lamont, 2005). Water droplets accumulate on the under-surface of the clear mulch which retain heat and insulate the seedbed. Ham et al. (1993) reported that soil temperatures averaged $6{ }^{\circ} \mathrm{C}$ greater under the clear polyethylene mulch than in non-covered seedbeds, depending on depth in the soil profile. It is theorized that solarization controls weeds by direct thermal killing of propagules, high temperatures interacting with toxic volatiles from decaying organic matter that weaken weed propagules so they are predisposed to microbial infection, and breaking 
propagule dormancy followed by scorching of trapped weeds under the clear solarization mulch (Rubin and Benjamin, 1983).

Solarization has been shown to control a broad array of plant pests including weeds, nematodes, fungi, and insects (Linke, 1994, Overman, 1985; Rosskopf et al., 2005). In general terms annual weeds are more effectively controlled than perennial weeds by solarization (Chase et al., 1998; Linke, 1994; Rubin and Benjamin,1983; Stevens et al., 1990).

Douglas and Sanders (2001) stated that the advantages of using plastic mulches are: increasing soil temperature from 4 to $5{ }^{\circ} \mathrm{C}$ under black mulch, 5 to $8^{\circ} \mathrm{C}$ with infrared transmitting mulch (clear green), or 8 to 10 ${ }^{\circ} \mathrm{C}$ at a $5 \mathrm{~cm}$ depth under clear mulch, reducing soil compaction, reducing evaporation, reducing weed problems, earlier crops and increasing growth.

The objective of the present study was to evaluate the effects of different soil moisture contents on soil temperature and soil solarization efficiency of the soil borne fungi under Libyan conditions.

\section{MATERIAL AND METHODS}

\subsection{Location and experimental design}

This investigation was conducted at Faculty of Agriculture, Omar AlMukhtar University, El-Beida, Libya (عمر المختار، البيضـاء), during the period from 15 th. of May to 15 th. of August 2010, to determine the effect of solar energy on these fungi in the soil. The Experiment is located at $30^{\circ} 45^{\prime} 16^{\prime \prime} \mathrm{N}$ latitude and $21^{\circ} 42^{\prime} 37.9^{\prime \prime}$ E longitude at an altitude of $612 \mathrm{~m}$ above mean sea level, by using GPS device (GRAMIN OLATHE, KS, USA).

The experimental plots of each soil were pre-irrigated at various intervals, to produce different moisture contents prior to covering the soil by black and transparent polyethylene with 100 microns thickens. The irrigation intervals were 20, 15, 10, 5 and 1 day (M1, M2, M3, M4 and M5, respectively). Thus, the wettest plot was the one irrigated 1 day before mulching. The plot size was $3 \times 6 \mathrm{~m}$. A $3 \mathrm{~m}$-wide buffer zone was maintained between plots. 


\subsection{Particle size distribution}

The soil of the site is a typical clay loam soil, composed of $40.8 \%$ sand, $27.2 \%$ silt, $32 \%$ clay, $0.47 \%$ organic matter and bulk density $1.21 \mathrm{~g} / \mathrm{cm}^{3}$. The test was carried out in soil department in the Faculty of Agriculture.

The following parameters were monitored: moisture content, soil temperature and microbial properties (solarization efficiency).
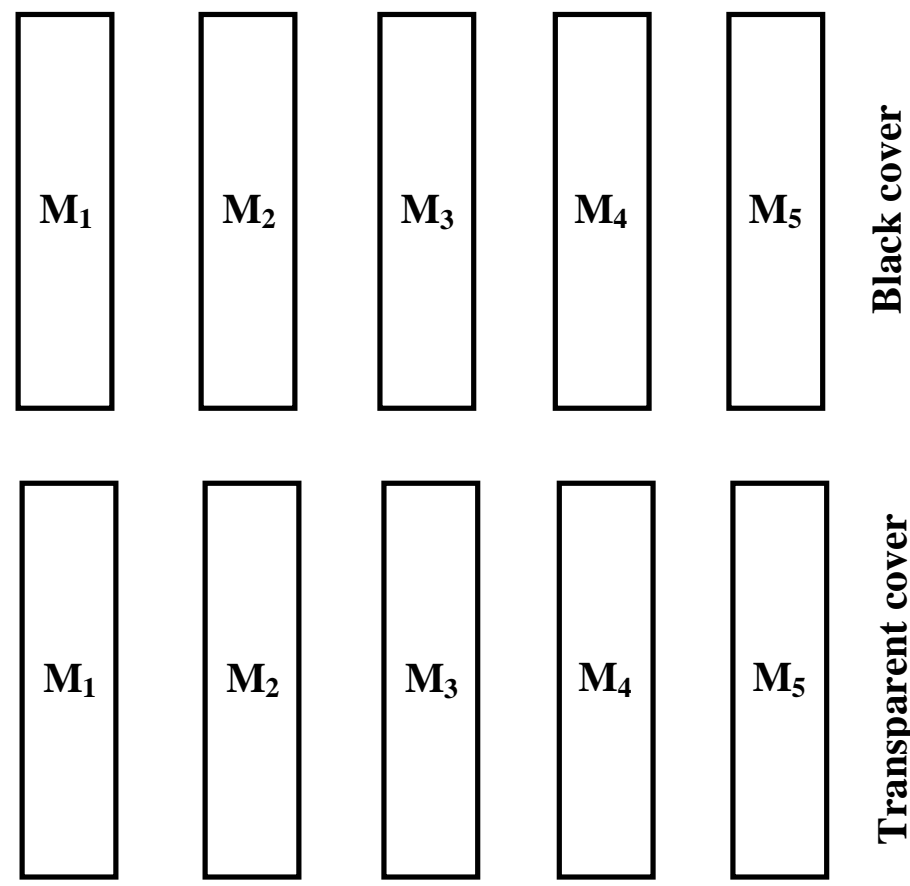

हैं

$M_{1}-M_{2}$ : Different moisture content.

Figure (1): Sketched experiment.

\subsection{Soil preparation}

A soil solarization experiment was performed for a period of 12 weeks during the summer of 2010. Soil to be solarized was tillage to a depth of at least $30-40 \mathrm{~cm}$. Soil preparation should focused on creating a fine textured matrix with only small soil particles and pores. This is essential to allow moist air to penetrate the soil particles and reach the place where soil borne pathogens are. This is achieved by deep cultivation followed by harrowing (disk harrow) and light rolling. 
The field was irrigated to a depth of $1 \mathrm{~m}$ to water holding capacity before mulching $\left(\boldsymbol{M}_{1}, \boldsymbol{M}_{2}, \boldsymbol{M}_{3}, \boldsymbol{M}_{4}\right.$, and $\left.\boldsymbol{M}_{5}\right)$. While covering, the edges of the plastic sheet were firmly embedded in the soil, preferably in shallow trenches, to ensure tightness and avoid the danger of the sheet being pulled by the wind. Two edges of polythene sheets should be inserted in the furrows. The edges should be buried and the top sheet opened out, as pages of a book. The process may be repeated, by aligning another sheet with a free edge, burying the edges and opening the sheets, until the required area is covered with sheeting. All free edges should be buried and the soil around them compacted so as to prevent escaping of heated air or soil moisture.

\subsection{Soil moistures measurement}

Various soil moistures were used for the experiments. The samples were collected at a depth of $0-30 \mathrm{~cm}$ in the soil. The soil moisture was estimated gravimetrically. The moisture content of the soil was determined by drying samples to constant weight in an oven at $72^{\circ} \mathrm{C}$. The moisture content of soil $(\boldsymbol{M})$ in percent (d.b.) was calculated as:

$$
M=m_{w} / m_{S}
$$

Where

$\boldsymbol{m}_{w}$ : The mass of water in the soil $(\mathrm{kg})$.

$\boldsymbol{m}_{\boldsymbol{d}}$ : The mass of dry soil particles $(\mathrm{kg})$.

The water content of soil on a volumetric basis $\boldsymbol{\theta}\left(\mathrm{m}^{3} / \mathrm{m}^{3}\right)$ :

$$
\theta=V_{w} / V_{t}
$$

Where

$V_{w}:$ Water volume $\left(\mathrm{m}^{3}\right)$.

$V_{t}$ : Total soil volume $\left(\mathrm{m}^{3}\right)$.

The volumetric soil water content $\boldsymbol{\theta}$ and the gravimetric soil water content $\boldsymbol{M}$ have the following relationship:

$$
\theta=M\left(\rho_{b} / \rho_{w}\right)
$$

Where

$\rho_{b}$ : The oven-dry bulk density $\left(\mathrm{kg} / \mathrm{m}^{3}\right)=\boldsymbol{m}_{\boldsymbol{s}} / \boldsymbol{V}_{\boldsymbol{t}}$.

$\rho_{w}:$ Water density $\left(\mathrm{kg} / \mathrm{m}^{3}\right)$.

$M s$ : The mass of dry soil particles $(\mathrm{kg})$. 


\subsection{Soil temperature measurement}

Soil temperature at $0-30 \mathrm{~cm}$ soil depth was recorded from 1 st. of June to 30 th. of July. Soil temperatures at depths of 10, 20 and $30 \mathrm{~cm}$ were monitored by means of shielded copper-constantan thermocouples (TEMPERATURE SENSOR METER CONTROL UNIT- PHILIP HARRIS- UK).

Daily soil minimum and maximum temperatures were recorded at 8.00 and $14: 30 \mathrm{~h}$ respectively from the three randomly selected places of different plots.

\subsection{Climatological data}

Table (1) shows the main characteristics of soil and climate at the experiment field. The general features of the global solar radiation measured by the Shahat (شحات) meteorological station .

Table (1): Main characteristics of climate at the experiment field (2010 mean data)

\begin{tabular}{|l|c|c|c|c||}
\hline Climate & May & June & July & August \\
\hline Min temp. $\left({ }^{\circ} \mathrm{C}\right)$ & 25.6 & 27.7 & 27.6 & 28.6 \\
\hline Max temp. $\left({ }^{\circ} \mathrm{C}\right)$ & 13.3 & 14.3 & 16.0 & 16.7 \\
\hline Mean temp. $\left({ }^{\circ} \mathrm{C}\right)$ & 16.5 & 18.1 & 19.3 & 20.1 \\
\hline Daily insolation (h/d) & 9 & 9 & 10.3 & 11.3 \\
\hline $\begin{array}{l}\text { Annual average observed } \\
\text { global solar radiation } \\
\left(\mathrm{W} \mathrm{h} / \mathrm{m}^{2} \text { day) }\right.\end{array}$ & \multicolumn{4}{|c||}{4504.17} \\
\hline
\end{tabular}

\subsection{Solarization efficiency}

To evaluate the effectiveness of the different soil irrigation regimes prior to soil solarization in controlling soil-borne fungi which cause plant diseases, soil samples infested with Fusarium and others were buried in the soil at depths of 10, 20 and $30 \mathrm{~cm}$, with three replicates at each depth. Before and after (4 and 8 weeks) solarization, three samples of the infested soil were examined in the Laboratory of Plant Pathology Department, and the percentages of dead fungus determined. The phytopathological procedure used in this study was described in detail by Dhingra and Sinclair, 1995; Tuite, 1969; Toussounand and Nelson, 1976; Barnett et al., 1998; Mathur and Kongsdal, 2003. 


\section{RESULTS AND DISCUSSION}

\subsection{Effects of soil solarization on soil moisture}

The variations in volumetric soil moisture content, for the upper $30 \mathrm{~cm}$ layer with different covers, during the solarization period are shown in Fig. (2). Soil mulching practically eliminates evaporation. Moreover, the drying trend of mulched soils is markedly reduced, and almost no diurnal effect in moisture variation is predicted. This is due to the fact that evaporation during the day is the main reason for the diurnal cycle. However, the evaporated soil moisture condenses on the polyethylene mulch and drips onto the soil surface. Hence, some days after the plots were mulched; the upper part of all plots was rewetted to a certain degree, depending on its moisture at the time of mulching.

For black cover, the values of moisture content $\left(\boldsymbol{M}_{1}, \boldsymbol{M}_{2}, \boldsymbol{M}_{3}, \boldsymbol{M}_{4}\right.$, and $\boldsymbol{M}_{5}$ ) at the start of solarization were $0.1,0.195,0.3,0.38$ and $0.48 \mathrm{~m}^{3} / \mathrm{m}^{3}$, these values at the end of solarization were $0.03,0.08,0.23,0.285$ and $0.39 \mathrm{~m}^{3} / \mathrm{m}^{3}$.

For transparent cover, the values of moisture content $\left(\boldsymbol{M}_{1}, \boldsymbol{M}_{\mathbf{2}}, \boldsymbol{M}_{3}, \boldsymbol{M}_{4}\right.$, and $\left.M_{5}\right)$ at the start of solarization were $0.081,0.185,0.286,0.369$ and $0.46 \mathrm{~m}^{3} / \mathrm{m}^{3}$. These values at the end of solarization were $0.014,0.062$, $0.221,0.270$ and $0.375 \mathrm{~m}^{3} / \mathrm{m}^{3}$.

The moisture content with transparent cover was less than with black cover. This may be due to that the temperature with transparent cover is higher than black cover.

This diurnal fluctuation causes moisture in the upper zones in soil to move downward during the day as a result of solar radiation, while at night the soil surface cools and causes an upward migration of moisture. As the soil solarization deepens in the soil, the movement of moisture becomes more pronounced, changing the distribution of salts and improving the tilth of the soil (Thus more humidity is maintained in the air space above soil.

\subsection{Soil temperature}

During 24 hours, the behavior of temperature curves illustrated in Fig. (3) indicated that the soil temperature decreased until 8:00 (morning) after 
which the soil temperature started to increase and reaches to its apex at noon (14:00). Then, the soil temperature decreased again during night and continued to decrease to its lowest value at 8:00, and so on.

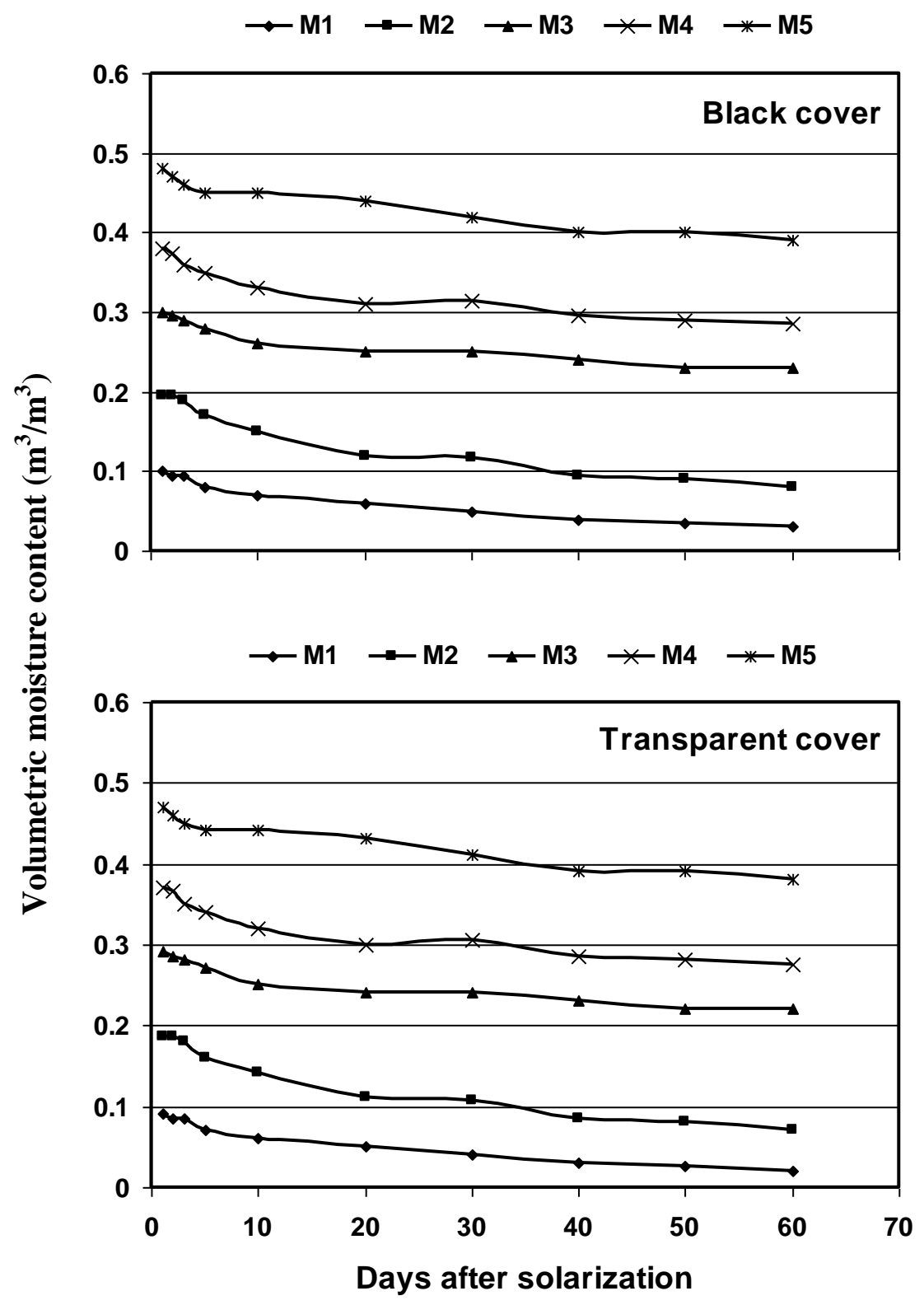

Fig. (2): The variation in soil moisture content for the upper soil layer $(0-10 \mathrm{~cm})$ for all mulched treatments. 


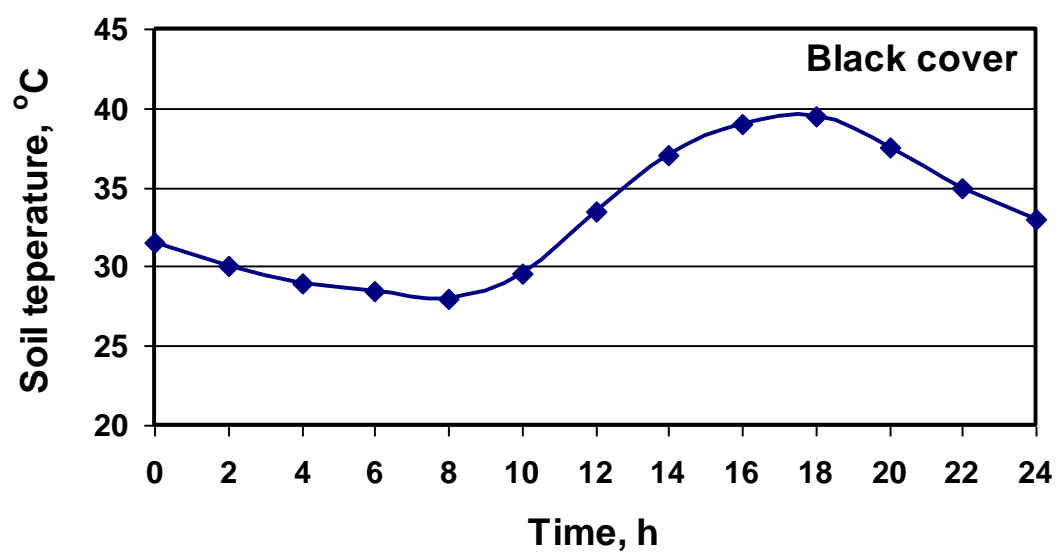

Fig. (3): Diurnal patterns of soil temperature at the $10-\mathrm{cm}$ depth with black cover at 6 th. of June.

Maximum and minimum soil temperatures under different moisture contents and depths are presented in Table (2).The results showed that the soil temperature during daytime (Max temperature) decreased with increasing depth, while soil temperature (Min temperature) increased with increasing depth at night. Also, the soil temperature during daytime (Max temperature) decreased with increasing moisture content, while soil temperature (Min temperature) increased with increasing moisture content at night.

Differences in maximum soil temperatures, as well as minimum temperatures within the different moisture regimes of both soils, were evident, especially at the $10 \mathrm{~cm}$ depth.

The corresponding differences for 20 and $30 \mathrm{~cm}$ were smaller. The general trend, which can be seen clearly in Table (2), is a decrease of the maximum temperature with increasing moisture content at all investigated depths in both covers. However, there was an increase in minimum temperature with increasing moisture content. The decreases in maximum temperature were larger than the increases in minimum temperature. For example, there were differences of $10.6{ }^{\circ} \mathrm{C}$ and $10.7{ }^{\circ} \mathrm{C}$ in maximum temperature at the $10 \mathrm{~cm}$ depth between the wettest and 
driest plots of the black and transparent covers, respectively, whilst such differences in minimum temperatures at the same depth were $5{ }^{\circ} \mathrm{C}$ and $3.9{ }^{\circ} \mathrm{C}$. These differences are due to that the upper soil layers (upper 10 $\mathrm{cm}$ ) have a marked diurnal temperature fluctuation, cooling at night and heating to high temperature during sunlight hours.

Table (2): Maximum (Max.) and minimum (Min.) soil temperatures $\left({ }^{\circ} \mathrm{C}\right)$ of under different moisture content regimes at different depths.

\begin{tabular}{||c|c|c|c|c|c|c||}
\hline Soil depth (cm) & \multicolumn{2}{|c|}{ 10 } & \multicolumn{2}{c|}{ 20 } & \multicolumn{2}{c||}{30} \\
\hline Temperature $\left.\mathbf{(}^{\mathbf{0}} \mathbf{C}\right)$ & Max. & Min. & Max. & Min. & Max. & Min. \\
\hline Moisture content & \multicolumn{7}{|c||}{ Black cover } \\
\hline $\mathbf{M}_{\mathbf{1}}$ & 58.5 & 22.7 & 50.5 & 26.3 & 43.9 & 28.0 \\
\hline $\mathbf{M}_{\mathbf{2}}$ & 47.6 & 25.9 & 42.9 & 27.7 & 42.7 & 28.4 \\
\hline $\mathbf{M}_{\mathbf{3}}$ & 49.5 & 26.7 & 45.1 & 28.0 & 42.6 & 29.0 \\
\hline $\mathbf{M}_{\mathbf{4}}$ & 48.0 & 27.1 & 44.4 & 28.4 & 42.1 & 29.3 \\
\hline $\mathbf{M}_{\mathbf{5}}$ & 47.9 & 27.7 & 44.2 & 28.8 & 41.0 & 29.8 \\
\hline $\mathbf{M}_{\mathbf{1}}$ & 59.8 & 23.4 & 52.4 & 25.7 & 46 & 27.7 \\
\hline $\mathbf{M}_{\mathbf{2}}$ & 52.8 & 24.5 & 48.4 & 26.8 & 44.9 & 28.7 \\
\hline $\mathbf{M}_{\mathbf{3}}$ & 51.3 & 26.1 & 47.5 & 28. & 44.1 & 28.9 \\
\hline $\mathbf{M}_{\mathbf{4}}$ & 49.5 & 26.6 & 45.9 & 28.4 & 42.8 & 29.8 \\
\hline $\mathbf{M}_{\mathbf{5}}$ & 49.1 & 27.3 & 44.9 & 28.5 & 41.9 & 30.0 \\
\hline
\end{tabular}

\subsection{Solarization efficiency}

Soil moisture is a critical variable in soil solarization because it makes organisms more sensitive to heat and also transfers heat to living organisms (including weed seeds) in soil. The success of soil solarization depends on moisture for maximum heat transfer; maximization heat in soil increases with increasing soil moisture. At the same time soil moisture favors cellular activities and growth of soilborne microorganisms, thereby making them more vulnerable to the lethal effects of high soil temperatures associated with soil solarization.

For all treatment, solarization efficiency decreased with increasing soil depth, this is due to temperature decrease with increasing soil depth. 
The highest values of solarization efficiency were $95.8 \%$ and $99 \%$ with black and transparent covers respectively, at 10-cm depth $(8 \mathrm{~W})$. Also, the solarization efficiency for transparent cover is higher than black cover.

The moisture content $\boldsymbol{M}_{\boldsymbol{4}}$ of both covers was reflected in a faster eradication of the tested pathogenic fungus. Percentages of killing for the five moisture contents were in the order $\boldsymbol{M}_{\mathbf{4}}>\boldsymbol{M}_{3}>\boldsymbol{M}_{\mathbf{2}}>\boldsymbol{M}_{1}>\boldsymbol{M}_{5}$ (Table 3). Although the highest soil temperature prevailed at the moisture content $\boldsymbol{M}_{5}$, the killing efficiency was reduced. This may be due to the low thermal sensitivity of the fungus at this moisture content. Table (3) reveals that the percentage killing was faster and higher in the soil surface layer $10 \mathrm{~cm}$ and decreased gradually with soil depth. This can be ascribed to the lower soil temperatures achieved at deeper depths.

Results showed that the numbers of fungi recorded before the application of solarization were reached to 12 species from seven genera. The most important fungal pathogens recorded were Alternaria, Cladosporium, Pytium and Fusarium. After application, the highest number of fungi noticed decreased to one species (Fusarium) with the treatment of $\boldsymbol{M}_{\mathbf{4}}$ for black and transparent cover.

According to the conditions of this study, it can be concluded that repeated watering during solarization, which is often done by farmers, does not seem to be necessary to eradicate soil pathogens.

Table (3): Percentages of the tested pathogenic fungus killed under different irrigation regimes $(M 1-M 5), 4$ weeks $(4 \mathrm{~W})$ and 8 weeks (8W) after solarization.

\begin{tabular}{||c|c|c|c|c|c|c|c|c|c|c||}
\hline \multirow{2}{*}{$\begin{array}{l}\text { Soil } \\
\text { Depth } \\
\text { (cm) }\end{array}$} & \multicolumn{2}{|c|}{$\mathbf{M}_{\mathbf{1}}$} & \multicolumn{2}{|c|}{$\mathbf{M}_{\mathbf{2}}$} & \multicolumn{2}{c|}{$\mathbf{M}_{\mathbf{3}}$} & \multicolumn{2}{c||}{$\mathbf{M}_{\mathbf{4}}$} & \multicolumn{3}{|c||}{$\mathbf{M}_{\mathbf{5}}$} \\
\cline { 2 - 11 } & $\mathbf{4 W}$ & $\mathbf{8 W}$ & $\mathbf{4 W}$ & $\mathbf{8 W}$ & $\mathbf{4 W}$ & $\mathbf{8 W}$ & $\mathbf{4 W}$ & $\mathbf{8 W}$ & $\mathbf{4 W}$ & $\mathbf{8 W}$ \\
\hline $\mathbf{1 0}$ & 69 & 77.5 & 73.1 & 85.7 & 79.2 & 87.5 & 86.4 & 95.8 & 68.7 & 75.4 \\
\hline $\mathbf{2 0}$ & 60.1 & 72.5 & 63.6 & 79.8 & 73.5 & 83.4 & 77.4 & 93.6 & 55.5 & 69.1 \\
\hline $\mathbf{3 0}$ & 45.7 & 47.1 & 40 & 43 & 41.8 & 49 & 49.3 & 65.1 & 37.5 & 43 \\
\hline & \multicolumn{10}{|c||}{ Transparent cover } \\
\hline $\mathbf{1 0}$ & 71.9 & 79 & 80.6 & 86.5 & 83.9 & 90.1 & 93.3 & 99 & 65.2 & 85 \\
\hline $\mathbf{2 0}$ & 65.3 & 75.4 & 69.6 & 85 & 77.1 & 88.7 & 80.9 & 98.1 & 59 & 69.3 \\
\hline $\mathbf{3 0}$ & 40 & 46.8 & 45.3 & 48.9 & 45.3 & 53.1 & 57.4 & 63 & 35.4 & 45.6 \\
\hline
\end{tabular}




\section{CONCLUSION}

From the obtained results, it can be concluded that:

1. The maximum soil temperature during daytime decreased with increasing depth, while minimum soil temperature increased with increasing depth at night.

2. The maximum soil temperature during daytime decreased with increasing moisture content, while minimum soil temperature increased with increasing moisture content at night.

3. Solarization efficiency decreased with increasing soil depth, this due to temperature decreased with increasing soil depth.

4. The highest values of solarization efficiency were $95.8 \%$ and $99 \%$ with black and transparent covers respectively.

5. The solarization efficiency for transparent cover is higher than black cover.

6. The percentage killing of the tested pathogenic fungus was higher at the volumetric moisture content $\boldsymbol{M}_{4}\left(0.39\right.$ and $0.37 \mathrm{~m}^{3} / \mathrm{m}^{3}$ at start solarization) for black and transparent covers respectively .

7. Solarization processing time could be carryed out from 4 to 8 weeks when using solarization with transparent and black covers.

8. Repeated watering during solarization, which is often done by farmers, does not seem to be necessary to eradicate soil pathogens.

\section{REFERENCES}

Al-Kayssi, A. W. and A. Al-Karaghouli. 1991. Influence of different colored plastic mulches used for soil solarization on the effectiveness of soil heating. Soil Solarization;109:297-308.

Avissar, R., Y. Mahrer, L. Margulies and J. Katan. 1986. Field aging of transparent polyethylene mulches: I. Photometric properties. Soil Sci. Soc. Am. J.;50:202-5. 
Barnett, H. L. and B. B. Hunter. 1998. Illustrated genera of imperfect fungi. The Am. Phytopathological Soc.: 130- 132.

Chase, C. A., T. R. Sinclair, D. G. Shilling, J. P. Gilreath and S. J. Locascio. 1998. Light effects on rhizome morphogenesis in nutsedges (Cyperus spp.): Implications for control by soil solarization. Weed Sci. 46, 575-580.

Dhingra, O. D. and J. B. Sinclair. 1995. Basic plant pathology methods. CRC Press, Inc. Boca Raton, FL. 435pp.

Di Primo, P., A. Gamiliel, M. Austerwell, B. Steimer, I. Peretz-Alon and J. Katan. 2003. Accelerated degradation of metam-sodium and dazomet in soil: Characterization and consequences for pathogen control. Crop Protection, 22, 635-646.

Douglas, C. and G. Sanders. 2001. Using Plastic Mulches and Drip Irrigation for Vegetable Gardens, Pub. North Carolina Coop. Ext. Servi. Rev. 1/01 HIL-8033.

Ham, J. M., G. J. Kluitenberg and W. J. Lamont. 1993. Optical properties of plastic mulches affect the field temperature regime. J. Am. Soc. Hort. Sci. 228: 188-193.

Horowitz, M., Y. Regev and G. Herzlinger. 1983. Solarization for weed control. Weed Sci;31:170-9.

Katan, J., A. Greenberge, H. Alon and A. Grinstein. 1976. Solar heating by polyethylene mulching for the control of diseases caused by soilborne pathogenes. Phytopathology;66:683-8.

Katan, J. (1984). Soil solarization, II I. Symp. Soil Disinfestations. Acta Hort, 152: 227-236.

Lamont Jr., W. J. 2005. Plastics: modifying the microclimate for the production of vegetable crops. Hort. Tec. 15: 477-481. 
Linke, K. H. 1994. Effects of soil solarization on arable weeds under Mediterranean conditions: control, lack of response or stimulation. Crop Prot. 13: 115-120.

Mathur, S. B. and O. Kongsdal. 2003. Common laboratory seed health testing methods for detecting fungi. I. Seed Testing Assoc. Bassersdorf, CH- Switzerland: 425.

Overman, A. J. 1985. Off-season land management, soil solarization, and fumigation for tomato. Proc. Soil Crop Sci. Soc. Fla. 44: 3539.

Rosskopf, E. N., D. O. Chellemi, N. Kokalis-Burelle and G. T. Church. 2005. Alternatives to methyl bromide: a Florida perspective. Plant Health Progress. (last accessed 27 Nov. 2011) / http://www. plantmanagementnetwork.org/ sub/php/review/2005/methylbromide/ MeBrAlternatives.pdf.

Rubin, B. and A. Benjamin. 1983. Solar heating of the soil: Effect on weed control and on soil-incorporated herbicides. Weed Sci. 31: 819-825.

Stevens, C., V. A. Khan, T. Okoronkwo, A. Y. Tang, , M. A. Wilson, J. Lu and J. E. Brown. 1990. Soil solarization and dacthal: influence on weeds, growth, and root microflora of collards. Hort. Sci. $25,1260-1262$.

Toussoun, T. A. and P. E. Nelson. 1976. Fusarium, a pictorial guide to the identitfication of Fusarium species according to the taxonomic system of snyder and Hansen. 2 nd. Ed. The pennsylvania State University Press, University Park and London: 43pp

Tuite, J. 1969. Plant pathological methods of fungi and bacteria. Minneapolis. Burgess: 239pp. 


\section{الملخص العربى \\ تأثير المحتوى الرطوبى على كفاءة التعقيم الثمسى للتربة

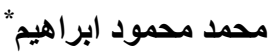

يعتبر التعقيم الثممسي للتربة الزر اعية أسلوب بديل للمكافحة الكيميائية للعديد من آفات التزبـة

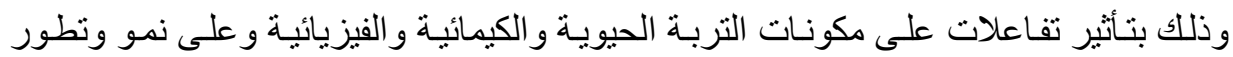

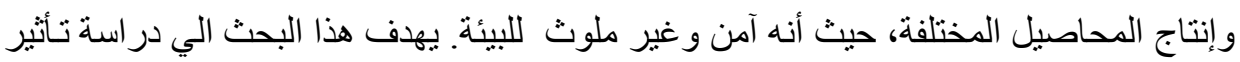

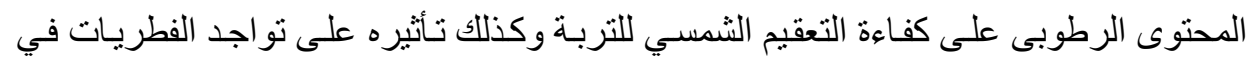

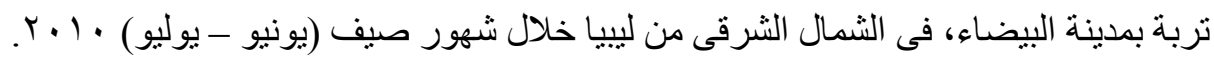
قسمت الأرض في التجربتين بعد تحضير ها إلى عشر قطع بأبعاد (؟×7) م بحيث تفصل بينهما

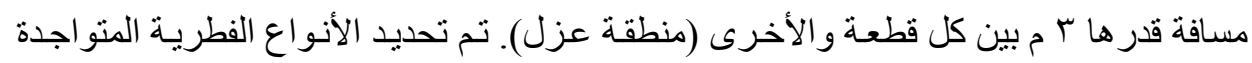

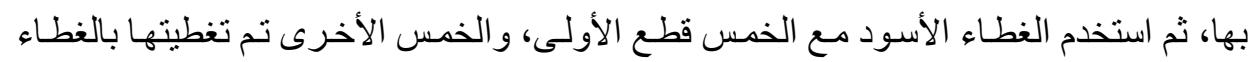

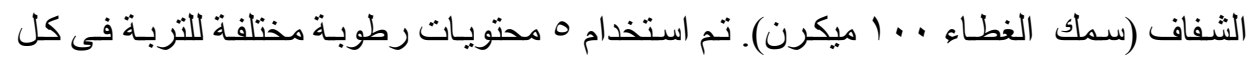

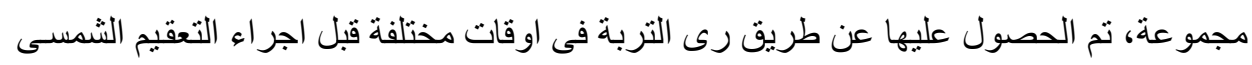

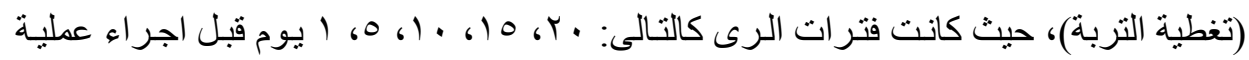
التعقيم وقد بينت النتائج التالمى: '. . أقصى درجة حرارة للتربة (اثثاء النهار ) تقل مع زيادة عمق التربـة، بينمـا أقل درجـة

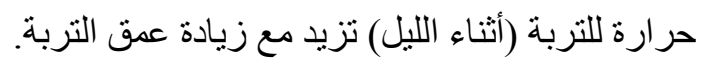
r. أقصى درجة حرارة للتربـة (اثناء النهار ) تقل مع زيادة المحتوى الرطوبى للتربـة،

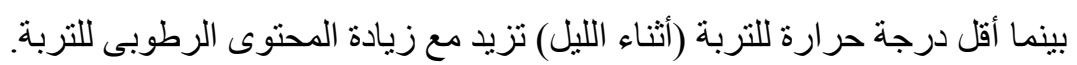

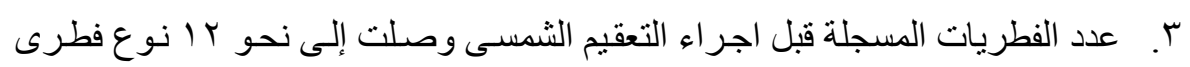

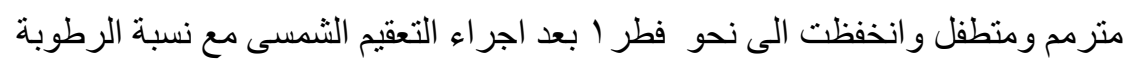

. $\left(M_{4}\right)$

* مدرس الهندسة الزراعية ـ كلية الزراعة ـ جامعة القاهرة. 
ــ. كفاءة التعقيم الثمسى تقل بزيادة عمق التربة.

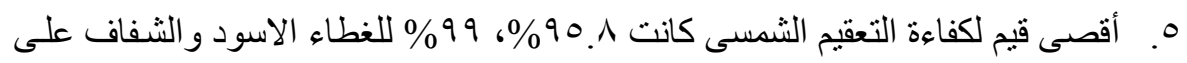

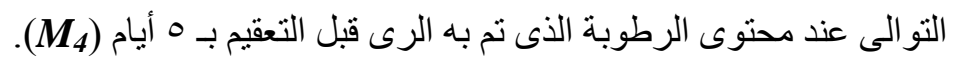
7. تؤثر الطاقة الثمسية على الطبقة السطحية بزيادة درجة الحر ارة أكثر من الطبقات الأعمق للتربة.

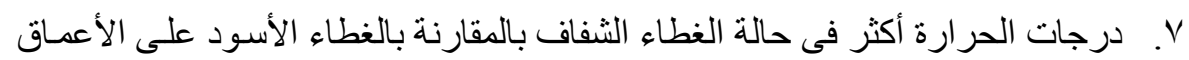

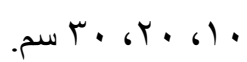

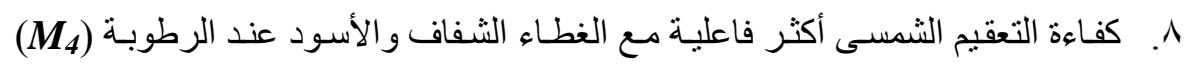

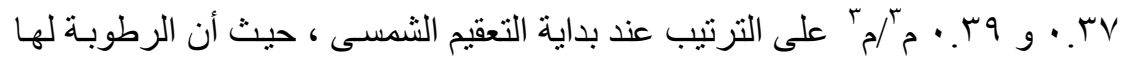
دور كبير فى تأثثر ها على فطريات التربة. 9. يمكن ان يتم التعقيم الثمسى فى خلال فترة زمنيـة من أربعـة إلى ثمانيـة أسـابيع خـلال شهور الصيف.

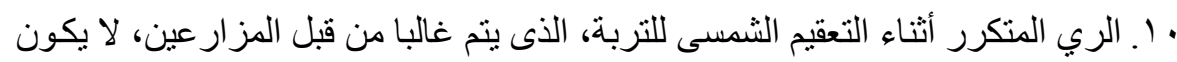

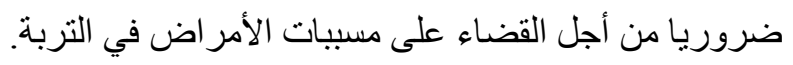

